\title{
Quality of Life and Women's Descriptive Representation: Female Emergence and Success in the 2018 Czech Local Elections ${ }^{1}$
}

\section{PAVEL MAŠKARINEC ${ }^{* 2}$}

* Department of Political Science, Faculty of Arts, Jan Evangelista Purkyně University in Ústí nad Labem, Czech Republic

\begin{abstract}
The aim of this paper is to analyse the effect of quality of life, together with other factors, on female candidates' willingness to run for office and women's descriptive representation in the 2018 Czech local elections. We found that the effect of some variables was different in the case of women's emergence and success. While the share of female candidates was higher in larger cities with lower quality of life and less nationalized local party systems, women were much more successful in smaller cities with lower quality of life, less nationalized local party systems and a more strongly gendered context in the sense of previous female representation, both in city councils and on corporate boards of firms owned by the city. While the positive effect of size on women's emergence can be explained with the larger city's context which generates more access points for emergence of women candidates, the negative effect of size on women's success was due to the desirability of office effect. Furthermore, the very small effect of previous female representation on the share of female candidates can be explained by the existence of an incumbency effect, which may also underlie the different influence of the representation of women in municipally-owned firms' management. Finally, the negative effect of quality of life (at the level of both candidacy and representation) can also be linked with the desirability hypothesis. The drive to win representation and make decisions about the life of the community can be expected to be much stronger in municipalities with higher quality of life.
\end{abstract}

\section{Keywords}

Quality of life, women's descriptive representation, local politics, quality of democracy, Czech Republic

DOI: https://doi.org/10.24132/cejop_2020_2

How to cite: Maškarinec, P. 2020. “Quality of Life and Women’s Descriptive Representation: Female Emergence and Success in the 2018 Czech Local Elections." Central European Journal of Politics 6 (2): 2343. DOI: 10.24132 /cejop_2020_2

\footnotetext{
1 The paper was prepared under a project supported by the Czech Science Foundation, Grant No. 20-04551S, "Patterns of Quality of Democracy at Regional Level in the V4 Countries: Looking Inside the Black Box".

2 Address: Doc. Mgr. Pavel Maškarinec, Ph.D., Associate Professor, Department of Political Science, Faculty of Arts, Jan Evangelista Purkyně University, Pasteurova 3571/13, 40096 Ústí nad Labem, Czech Republic. E-mail: maskarinec@centrum.cz
} 


\section{Introduction}

Quality of life (QoL) and women's representation in politics are two of the most studied issues in many areas of social sciences and beyond. However, research that aspires to connect the issue of quality of life with the level of female participation in political decision-making processes (as one of the dimensions of quality of democracy [Lijphart 2012; Gwiazda 2016]) is still largely missing, primarily at subnational levels of government both regional and especially local, which are seen by many as places where (men's as well as women's) political careers begin. Similarly, there is also almost no research on quality of life in general political science literature on the effect of quality of life on many areas of politics at all levels of government. However, as some previous studies in the Czech Republic confirmed the effect of quality of life on, for instance, electoral behaviour in presidential elections (Murgaš 2019), or on voter turnout in local elections (Haman and Školník 2020), ${ }^{3}$ we will try to expand the quality of life research to cover the area of women's representation as well.

The aim of this paper is to analyse the effect of quality of life, as well as other determinants, on both female candidates' willingness to run for office and women's descriptive representation in the 2018 local elections in Czech cities, or more specifically municipalities with extended powers. The paper is organised as follows. First, we briefly review the existing literature on quality of life and determinants of women's representation. In the second part, the data and methods of analysis are introduced. In the third part, a regression analysis of women's emergence and success in Czech cities is presented. Finally, the concluding section formulates some implications of the results for further research.

\section{Theoretical framework}

\subsection{Quality of life}

Most authors argue that quality of life is a complex, multidimensional and amorphous concept without a generally valid definition, as well as without a uniform methodology of measurement (Phillips 2006; Ira and Andráško 2007; Rišová and Pouš 2018; Murgaš 2016; Murgaš and Drápela 2020; Faka 2020). At the same time, it has been argued that the conceptualization of quality of life is based on two dimensions: subjective (personal) and objective (spatial) (Murgaš and Petrovič 2020). While the subjective dimension of quality of life is referred to as subjective well-being, the objective one is referred to as

\footnotetext{
${ }^{3}$ In the presidential elections of 2013 and 2018, better quality of life in a district meant worse outcome for Miloš Zeman - the winning candidate of both presidential races (see Murgaš 2019). In Czech local elections, higher quality of life increases voter turnout in a given municipality (see Haman and Školník 2020).
} 
quality of place (cf. Phillips 2006: 15-36). Similarly, quality of life has been defined both in micro (individual, subjective) terms, including overall perceptions of quality of life, individual experiences and values (measured through such indicators as well-being, happiness, satisfaction with individual's own life or the environment where she/he lives and so on), and in macro (societal, objective) terms, including indicators of income, employment, housing, education, or other living conditions and environmental circumstances (Bowling and Windsor 2001).

However, Murgaš and Drápela (2020: 326) emphasized that it is not correct to connect quality of life research with subjective well-being or happiness, because quality of life does not equal subjective well-being (measured and evaluated by subjective satisfaction with individual's life). More importantly, with regard to spatial (or geographical) aspects of quality of life, Murgaš and Klobučník (2016) preferred the objective dimension of community (conceptualized as quality of place) as more important for quality of life research. The main reason is that quality of life always has a geographic dimension with both a spatial and a personal dimension, and the priority is to identify places (at different hierarchical levels) where quality of life is high, medium, or low (Murgaš 2016).

More importantly, although there is no generally valid method of measuring quality of life, many authors (Rinner 2007; Mizgajski, Walaszek and Kaczmarek 2014; Peach and Petach 2015; Weziak-Białowolska 2016; Bougouffa and Permana 2018; Kazemzadeh-Zow et al. 2018; Faka 2020; Murgaš and Petrovič 2020) have presented their own conceptualizations of quality of life, together with sets of indicators aimed at capturing various (spatial as well as non-spatial) aspects of quality of life. For instance, Murgaš and Klobučník (2016) calculated their index of quality of life at the level of all Czech municipalities using ten indicators: (1) suicides; (2) male life expectancy at birth; (3) female life expectancy at birth; (4) mortality; (5) birth rate; (6) divorce rate; (7) college-educated population; (8) unemployment; (9) emission balance; and (10) generativity (cf. Murgaš and Klobučník 2016: 556-558).

This paper uses the complex Quality of Life Index developed by Obce v datech (2020) to evaluate the effect of quality of life on female participation in local political decision making. The index combines several indicators of the happiness and welfare of people's lives in three basic dimensions: (1) health and environment; (2) work, education and standard of living; (3) community and services - and each of these dimensions is composed of several indicators.

\subsection{Determinants of women's representation}

With regard to determinants of women's representation, it is possible to define three groups of variables which explain cross-national variation in the number of women 
elected to national parliaments, namely: (1) socioeconomic factors; (2) cultural factors; and (3) political and institutional factors (Norris 1987; Siaroff 2000; Krook 2010). However, other authors demonstrate that women's representation at the local level is a complex phenomenon that can be shaped by both local political context and institutional variables (Smith, Reingold and Owens 2012), previous officeholder's experience (Trounstine 2011), strategic context (Crowder-Meyer and Smith 2015), as well as by candidates' personal characteristics that may express their political ambitions to run for (and win) a representative post.

The theoretical framework of the present paper builds on the assumption that women's representation in Czech cities is differentially shaped by quality of life, which influences social and political behaviour, but at the same time, women's prospects further depend on the context, i.e., exogenous factors that may strengthen or weaken their chances of running in elections or to run in elections or of getting elected.

Even though the significance and direction of the relationship between quality of life and the level of women's representation in local politics is not clear (given the lack of pertinent research), we follow the assumptions of modernization theory (Inglehart 1997; Inglehart and Norris 2003; Inglehart, Norris and Welzel 2002; Inglehart and Welzel 2005) that economic development is the driving force of value change in society, culture and politics, and cities with higher quality of life (indicating higher standards of living and human development) are more likely to have both more female candidates in local elections and more female councillors in their local councils. It may therefore be expected that:

$\boldsymbol{H}_{1}$ : The proportion of female candidates will be higher in cities with higher quality of life. $\boldsymbol{H}_{2}$ : The proportion of female councillors will be higher in cities with higher quality of life.

In addition to quality of life, we focus on four factors that may give rise to a strategic environment fostering women's chances of getting involved in decision making in local political affairs. Those factors include municipality size and local party system's nationalisation as indicators of external environment (an institutional, exogenous factor), complemented by contextual variables that identify whether the local environment is more open to women's representation given the previous level of women's representation at the local level both in local councils as well as on corporate boards of firms which are owned by Czech cities.

Population size is considered as one of the key variables affecting the form of local politics. ${ }^{4}$ However, although population size is primarily a demographic factor, it is also

\footnotetext{
${ }^{4}$ In the Czech case, see, e.g., Ryšavý and Šaradín (2010), Ryšavý and Bernard (2013), Balík, Gongala and Gregor (2015), Kruntorádová (2015), Maškarinec (2015), Lysek (2016), Vogt (2017), Spáč et al. (2018),
} 
often used as one of the factors affecting the desirability hypothesis. The latter applies to the Czech Republic, where the district magnitude is derived precisely from municipality size. ${ }^{5}$ However, while studies of state legislatures (Carrol 1994) show that men should be more likely to run for and win offices that are seen as more prestigious and whose members have more decision-making powers, most studies at the local level which examined the association between women's political representation and different measures of desirability show only limited or at best mixed support for this hypothesis (Karnig and Walter 1976; Welch and Karnig 1976; Bullock and MacManus 1991; Alozie and Manganaro 1993; Smith, Reingold and Owens 2012; Crowder-Meyer and Smith 2015; Crowder-Meyer, Kushner Gadarian and Trounstine 2015).

More importantly, in the Czech case, too, there is a considerable effect of size on female representation. That effect, though, was not constant in our findings. We were unable to confirm the assumed negative effect of municipality size on women's representation in the smallest municipalities (population under 150) or in municipalities of 1,001-2,000 inhabitants, but also in medium-sized towns with 15,001-40,000 inhabitants (cf. Maškarinec 2019b: 145-156). These divergent effects of municipality size may provide a partial explanation for the fact that the finding from traditional democracies that women are more successful in larger municipalities does not apply in the Czech Republic. This is another manifestation of the effect of the country's extremely fragmented settlement structure, which may have divergent influence on women's political representation as well. At the same time, this conclusion is consistent with the findings of other authors (Balík, Gongala and Gregor 2015), who talk about "three worlds" of local elections in the Czech Republic with regard to the electoral system's effects in municipalities of different sizes: the largest cities experience considerably weaker effects of preferential voting on party list reordering, which translates into higher importance of the nomination process and a stronger role of party leadership in the composition of local councils (cf. Balík, Gongala and Gregor 2015: 64-68). Keeping these conclusions in mind we suggest that:

$\boldsymbol{H}_{3}$ : The proportion of female candidates will be higher in larger cities.

$\boldsymbol{H}_{4}$ : The proportion of female councillors will be lower in larger cities.

According to some authors, voting for women for the first time is "innovative political behaviour, but successful innovations become routinised and diffused." (Ondercin and

\footnotetext{
Čopík, Kopřiva and Čmejrek (2019), Šaradín et al. (2019), Hájek and Balík (2020), Potluka, Svecova and Zarubova (2020), Voda and Svačinová (2020).

${ }^{5}$ Czech local councillors are elected under free-list proportional representation, and the number of seats on local councils varies between 5-15 seats in the smallest municipalities (population under 500), 35-55 seats in the largest cities (above 150,000 inhabitants) and 55-70 seats in the capital city of Prague.
} 
Welch 2009: 599) The fact that the existing share of women officeholders can have a positive impact on future representation of women was confirmed at the national level in an analysis of US congressional elections between 1992 and 2000 (Ondercin and Welch 2009), but also at the local level (Trounstine 2011; Smith, Reingold and Owens 2012; for an example of Czech cities between 1994-2014, see e.g. Maškarinec, Klimovský and Bláha 2019, or for regional cities in 2018, see Bláha and Maškarinec 2020).

Furthermore, the percentage of women in a city council was a positive predictor of the descriptive representation of women as mayors in subsequent years in US municipalities with a population of 100,000 or more (Smith, Reingold and Owens 2012), and similarly, there exists an effect in the opposite direction, i.e., a high correlation between the presence of a woman mayor and the proportion of female councillors (Regulska, Fried and Tiefenbacher 1991). On the other hand, only a weak effect of previous women's representation on subsequent election of female mayors has been indicated for Czech municipalities with extended powers and Slovak district towns (Maškarinec, Klimovský and Danišová 2018).

Most studies also confirm a very strong positive effect of incumbency (advantage over rival candidates of existing officeholders running for re-election) on candidates' success in local elections (Martinussen 2004; Trounstine 2011; Sloboda 2014; for contrary results on the incumbency effect on women's willingness to run or their success in local elections, see Spicer, McGregor and Alcantara 2017), which has been confirmed by some previous studies in the case of Czech municipalities (Bernard 2012). A role is played by experience, where women's success in lower positions may serve as a means to their subsequent success as mayoral nominees (Crowder-Meyer, Kushner Gadarian and Trounstine 2015). It may therefore be assumed that:

$\boldsymbol{H}_{5}$ : The proportion of female candidates will be higher in cities that have experienced more women in their local councils in recent years.

$\boldsymbol{H}_{6}$ : The proportion of female councillors will be higher in cities that have experienced more women in their local councils in recent years.

Similarly, a more friendly gendered context should be created not only by higher share of previous female councillors but also higher presence of women in other public posts. As we focus on the local level, a varying degree of women's representation on the boards of municipally-owned companies may result in differences in women's access to decisionmaking positions as one of the indicators of quality of democracy. In the Czech case, previous studies have found that women's representation in management positions decreases with growing decision-making level, which is corroborated by a comparative study of the corporate environment, where the number of women decreases with every single move up the management ladder (cf. Víšek, Dohnalová and Král'ová 2012: 20-22; Janský, Krotil and Pavlas 2015: 15-23). 
More importantly, research on the level of 26 largest Czech cities (statutory cities) showed that women (as members of supervisory boards and boards of directors of companies in which shares are owned by statutory cities) are significantly advantaged in cities whose political environment (culture) is characterised with more "openness" to women (i.e. those with more women in their city councils/city boards or especially those with female mayors). ${ }^{6}$ Furthermore, while municipality size had a negative effect on women's descriptive representation on supervisory boards, it increased their representation on boards of directors (see Maškarinec 2019a: 970-975). Keeping these conclusions in mind we suggest that:

$\boldsymbol{H}_{7}$ : The proportion of female candidates will be higher in cities that have experienced more women on the corporate boards of firms owned by them.

$\boldsymbol{H}_{8}$ : The proportion of female councillors will be higher in cities that have experienced more women on the corporate boards of firms owned by them.

Finally, another possible differentiating factor of women's representation is the shape of local party competition (in terms of the form of political competition between nationwide political parties, local parties or independent candidates), which choice is based on several arguments. On one hand, Czech local elections in smaller (and partly in mediumsized) municipalities are dominated by the phenomenon of independent candidates, and the role of political parties increases proportionally with increasing municipal size, which manifests itself most clearly in the case of statutory towns (cities with more than 40,000 inhabitants) where political parties dominate the electoral contest (Balík 2008).

Furthermore, there was a positive correlation between the proportion of seats received by independent candidates and women's descriptive representation on Czech local councils. This suggests that women prefer rather non-institutionalised (nonpartisan) forms of participation, or institutionalised independent local lists, respectively, which bring them much more success in their effort to engage in local politics (Ryšavý and Šaradín 2010; Maškarinec and Klimovský 2016). It may therefore be assumed that:

H9: The proportion of female candidates will be lower in cities with more nationalised local party systems.

$\boldsymbol{H}_{10}$ : The proportion of female councillors will be lower in cities with more nationalised local party systems.

\footnotetext{
${ }^{6}$ On the other hand, the positive effect of women's higher success rate as local councillors on descriptive representation of women on city boards existed only after some elections, while the share of female local councillors in previous elections had a negative effect on the number of women on city boards in the following elections (see Maškarinec 2016: 123-126).
} 


\section{Data and methods}

This paper works with the election outcomes in 205 Czech municipalities with extended powers and the capital city of Prague. The choice of such municipalities as basic units of analysis takes into account the peculiar settlement structure of the Czech Republic. It is characterised by a large number of small unintegrated municipalities, resulting in an extreme fragmentation of settlement system, reproduced in the equally fragmented structure of the local system of government (Illner 2003). ${ }^{7}$ This may also translate into significantly different levels of quality of life or quality of democracy across municipalities.

The outcomes of earlier studies demonstrated that the possibilities of direct application of some theories of political science (derived primarily from the practice of higher-level politics) on the reality of Czech local politics are significantly limited by the size of the local political systems analysed. According to most authors, it is the very size of municipalities which determines a functional model of local politics. For this reason, it is meaningless to work with the smallest categories of municipalities as they lack some aspects of classic political systems, and traditional theories of political partisanship and political race are not applicable there (Jüptner 2008).

By contrast, municipalities with extended powers represent natural centres of microregions, to a certain extent serving as local "models" in their districts (Balík 2008). Furthermore, municipalities with extended powers (including Prague) include only 3.3\% of all Czech municipalities, on one hand, but on the other hand, they contain nearly all the cities of more than 10,000 inhabitants in the Czech Republic and almost three-fifths $(56.56 \%)$ of the country's population, and it is unthinkable to select a more homogenous group of municipalities with so many members.

Our dependent variables measure the share of women among candidates for and winners of local legislative offices in a given city and election year. The variable percent of female candidates indicates the percentage of all candidates running for a given local legislature in an election year who are women while percent of female winners measures the percentage of all winners in a local legislature and election year who are women.

We use various independent variables to explain the varying levels of female emergence and success in Czech local elections. First, we include the Quality of Life Index developed by Obce v datech, a consulting company for local government. The Quality of Life Index consists of three dimensions: (1) health and environment; (2) work, education and standard of living; (3) community and services, and each of these dimensions is

\footnotetext{
${ }^{7}$ The structure of settlements in the Czech Republic is extremely fragmented. For example, municipalities with a population under 1,000 account for more than $77 \%$ of the country's 6,253 municipalities but only approximately $17 \%$ of the country's total population. For a full account of local authorities in the Czech Republic and the basic features of their autonomy, see Illner (2003).
} 
composed of several indicators. ${ }^{8}$ The Quality of Life Index calculations are based on OECD and UN approaches to benchmarking quality of life. The values of the indices range from 0 to 10 , where a municipality with the worst results is given the value of 0 and one with the best result is given the value of 10. Generally, the Quality of Life Index does not interpret the quality of individual objects as subjectively sufficient or insufficient, but it focuses on their relative number or availability compared to the municipality with the best number or availability (Obce $v$ datech 2020).

In the case of the effect of strategic (or gendered) electoral context, we use two indicators. With regard to previous studies, we expect a positive impact of previous share of women officeholders on future female representation. However, as the previous female councillors variable (share of female councillors in previous term) could be an endogenous predictor of the percentage of female winners in following elections (i.e. the dependent variable), we control for the effect of this independent variable including its lagged version, too (see below). Furthermore, as a more gendered electoral context (or context indicating more openness to women representation) might also indicate the presence of women in other public offices, we pay additional attention to the extent of female representation on corporate boards of firms which are owned by Czech cities, or more precisely on boards of directors and on supervisory boards. We expect that women will be significantly advantaged in cities whose political environment (culture) is characterised with more "openness" to women (i.e., those with more women in their city councils). To measure women's representation on the boards of companies in which the cities own shares, we used the so-called Gender Index, which indicates the number of women on supervisory boards and boards of directors as a proportion of the total number of positions in both these bodies, as adopted from the "gender map" database (Otevřená společnost 2020; see Janský, Krotil and Pavlas 2015). ${ }^{9}$

\footnotetext{
${ }^{8}$ The first dimension (health and environment) includes the following variables: index of practitioners; index of paediatricians; index of driving time to a hospital; index of pharmacies; index of life expectancy; index of air pollution; index of presence of polluters; index of protected natural areas. The second dimension (work, education and standard of living) includes: index of unemployment; index of available job offers published on job portals; index of available job offers published by the Labour Office; index of affordable housing; index of material insufficiency; index of financial distress; index of kindergarten capacity; index of elementary school capacity; index of quality high schools. And finally, the third dimension (community and services) includes: index of supermarkets; index of ATMs; index of restaurants; index of cinemas; index of road network; index of railway transportation; index of citizen engagement; index of participation in regional and municipal elections; index of traffic accidents; index of gambling; index of migrating young people; index of population increase. For more on the construction of the Quality of Life Index, see Obce v datech (2020).

${ }^{9}$ Czech business corporations are managed under the two-tier (so-called German) board system where authority is delegated to two bodies: boards of directors and supervisory boards. However, in the reality of Czech municipalities, the influence of boards of directors on corporate management strongly prevails.
} 
Furthermore, we include the municipality size variable (logarithm of the number of inhabitants) as a measure of both social diversity and desirability of local legislative offices. Finally, to capture the political nature of local elections (in terms of the shape of political competition between national parties, local parties and independents), we measure the degree of local party system nationalisation, employing Kjaer and Elklit's (2010) index of local party system nationalisation. ${ }^{10}$ This approach is an extension of previous research of party system nationalisation, which accentuated the significance of spatial aspects for overall institutionalisation of party systems almost exclusively at the level of party strength in national elections (Jones and Mainwaring 2003; Caramani 2004; Chhibber and Kollman 2004; Bochsler 2006, 2010; Kasuya and Moenius 2008; Harbers 2010, 2017; de Miguel 2017; in the Czech context Strmiska et al. 2009; Lyons and Linek 2010; Stauber 2017).

More specifically, we use Kjaer and Elklit's effective index of local party system nationalisation (LPSN), which can be expressed as the share of seats in the municipal council gained by national parties divided by the share of seats in the national parliament carried by the parties with no representation in the municipality +1 (for more on the construction of the index, see Kjaer and Elklit 2010: 431-436; for possibilities of using the index in the Czech context, see Maškarinec 2015: 631-638). ${ }^{11}$

The effects of the above-mentioned indicators (Table 1) are analysed using the classic ordinary least squares method (multiple linear regression). We estimate two separate models. Model 1 includes the non-lagged version of the previous female councillors variable, while Model 2 includes its versions lagged by one election cycle; one election cycle spans 4 years. With the exception of the Quality of Life Index and the Gender Index, the remaining independent variables, as well as the dependent variables, are sourced from the Czech Statistical Office's server (CZSO 2020).

\footnotetext{
${ }^{10}$ Kjaer and Elklit's (2010) approach, which the authors used in the context of Danish local elections, was later replicated in research of local party system nationalisation in other European countries: Austria (Ennser-Jedenastik and Hansen 2013), the Czech Republic (Maškarinec 2015) or Belgium (Dodeigne, Close and Teuber 2020). A partly different approach to research of nationalisation of local party systems was taken by Steyvers and Heyerick (2017) in Belgium.

${ }^{11}$ The underlying idea of the equation for calculating the effective index of local party system nationalisation is identical with the way the equation for calculating its non-effective version was constructed. The index equals the number of municipal council seats acquired by national parties as a share of the "potential size" of the council if unrepresented national parties obtained the same share of seats in the council as in the national parliament. Therefore, the denominator in the equation equals one plus the share of seats in the national parliament held by the parties without representation in a given municipality (Kjaer and Elklit 2010: 442). In its formalised version, the formula for calculating the effective index of local party system nationalisation would be as follows: $\operatorname{LPSN}=(x / y)+1$, where $x$ represents the share of seats in the council obtained by national parties and $y$ indicates the share of seats in the national parliament maintained by the parties which failed to acquire representation in the municipality.
} 
Table 1. List of variables and descriptive statistics

\begin{tabular}{|l|l|c|}
\hline Variables & Description & $\begin{array}{c}\text { Mean } \\
\text { (standard dev.) }\end{array}$ \\
\hline Dependent variable & Share of female candidates & $22.99(8.62)$ \\
\hline Dependent variable & Share of female councillors & $32.76(4.26)$ \\
\hline Quality of Life Index & Quality of life index & $4.36(1.23)$ \\
\hline Municipality size (log) & Logarithm of the number of inhabitants & $4.17(0.40)$ \\
\hline Previous female councillors & Share of female councillors in previous term & $22.52(8.76)$ \\
\hline Gender Index & $\begin{array}{l}\text { Share of women on supervisory boards and boards } \\
\text { of directors of companies in which cities own shares }\end{array}$ & $0.19(0.16)$ \\
\hline LPSN & Effective index of local party system nationalisation & $0.58(0.18)$ \\
\hline
\end{tabular}

Source: Author.

\section{Results}

The results of our models of women candidates and winners in the 2018 Czech local elections are presented in Table 2 (below). The empirical results show that the variables chosen explained women's emergence as candidates relatively consistently across both separate models, as well as the models for local councillors, but at the same time, some independent variables did not work in the same direction across the models. More importantly, with the exception of the non-lagged model for female winners (32\%), the remaining models explained only a small part of the dependent variable's variance and especially the use of lagged variables decreased the explanatory capacity of the models to only $8 \%$ (female candidates) or even $3 \%$ (female winners).

To start with the models which predict the proportion of female candidates for Czech city councils, our analysis demonstrates that the number of women who run for office slightly increases with local population (H2), but at the same time, it decreases in cities with more nationalised local party systems (H9). The contrasting effects of both variables can be somewhat explained by the fact that local party system nationalisation only slightly increases with municipality size (see Maškarinec 2015) - similarly to Belgium (Dodeigne, Close and Teuber 2020) or Austria (Ennser-Jedenastik and Hansen 2013) but in contrast to a much stronger relationship in Denmark (Kjaer and Elklit 2010) - and as a result, larger municipalities may not necessarily have more nationalised local party systems (for more on the gains of parliamentary and non-parliamentary parties in the largest Czech cities, see Šaradín 2004).

Similarly, we confirmed the expected positive effect of openness of local environment to women, in terms of women's previous representation. However, this applies only to the share of previous female officeholders in the same city (H5). On the 
contrary, the effect of the Gender Index (i.e., presence of women on supervisory boards and boards of directors of companies owned by the city) as well as the effect of quality of life countered our theoretical assumptions. As increasing values of both variables were associated with decreasing women's emergence in Czech local elections, we have to refuse $\mathrm{H} 7$ and $\mathrm{H} 1$.

However, as women's descriptive representation in the previous term would be an endogenous predictor of the percentage of female candidates in the following elections, Model 2 controlled for the effect of this independent variable, including its lagged version. However, inclusion of the lagged variable also had minor influence and resulted mostly in a somewhat weakening effect of the independent variables, without changing the direction of their effects on the dependent variable. The most significant change thus was the considerably weaker effect of local party system nationalisation index. The variable even changed the direction of its effect: the number of women candidates now grew with local party system nationalisation, although with a very minor effect. Similarly, there were weaker effect of the previous female councillors variable on the share of female candidates, which is in stark contrast to the strong effect of this variable on future representation of women found in previous Czech local elections between 1994 and 2014 (see Maškarinec, Klimovský and Bláha 2019: 63-73).

Table 2. Determinants of women's emergence and success in elections to Czech city councils, 2018 (OLS models)

\begin{tabular}{|l|c|c|c|c|}
\hline \multirow{2}{*}{} & \multicolumn{2}{|c|}{ Model 1 } & \multicolumn{2}{c|}{ Model 2 } \\
\cline { 2 - 5 } & $\begin{array}{c}\text { \% female } \\
\text { candidates }\end{array}$ & $\begin{array}{c}\text { \% female } \\
\text { winners }\end{array}$ & $\begin{array}{c}\text { \% female } \\
\text { candidates }\end{array}$ & $\begin{array}{c}\text { female } \\
\text { winners }\end{array}$ \\
\hline Quality of Life Index & $-0.873(0.277)^{* *}$ & $-0.309(0.465)$ & $-0.967(0.278)^{* * *}$ & $-0.809(0.551)$ \\
\hline Municipality size (log) & $0.243(0.888)$ & $-0.987(1.493)$ & $0.220(0.902)$ & $-0.800(1.787)$ \\
\hline Previous female councillors & $0.111(0.039)^{* *}$ & $0.544(0.065)^{* * *}$ & $0.086(0.042)^{*}$ & $0.217(0.083)^{* *}$ \\
\hline Gender Index & $-2.084(2.124)$ & $1.171(3.570)$ & $-1.707(2.150)$ & $2.960(4.259)$ \\
\hline LPSN & $-0.445(2.163)$ & $-2.817(3.635)$ & $0.066(2.201)$ & $-1.213(4.359)$ \\
\hline Constant & $33.718(3.824)^{* * *}$ & $17.459(6.428)^{* *}$ & $34.443(3.873)^{* * *}$ & $24.940(7.671)^{* * *}$ \\
\hline N & 206 & 206 & 206 & 206 \\
\hline Adj. $\boldsymbol{R}^{\mathbf{2}}$ & 0.105 & 0.323 & 0.080 & 0.034 \\
\hline
\end{tabular}

Source: Author.

Note: The table presents coefficient estimates with standard errors in parentheses. Statistical significance level: ${ }^{* * *} p<0.001,{ }^{* *} p<0.01,{ }^{*} p<0.05$. Model 1 includes the non-lagged version of the previous female councillors variable, while Model 2 includes its versions lagged by one election cycle; one election cycle spans 4 years. 
To sum up, in contrast to our expectations, the cities with higher quality of life were not among those where women were willing to run in higher numbers than in municipalities with worse levels of quality of life, as measured in the domains of health and environment, work, education and standard of living, or community and services. Similarly, also the effect of gendered electoral context on women's candidacy was only small or even negative, which suggests that different levels and places of political decision making occupied by women do not necessarily interact to the same extent, as indeed testified by the weak effect of previous women's representation on subsequent election of female mayors (Maškarinec, Klimovský and Danišová 2018). Overall, the share of female candidates was higher in larger cities with lower quality of life and less nationalised local party systems.

Moving on to models which assess the effects of our independent variables on women's success in Czech city councils in 2018 local elections, our analysis demonstrates, in contrast to most findings from traditional Western democracies but in line with $\mathrm{H} 4$ (the desirability of office argument), that women's descriptive representation on Czech councils is much lower in cities with larger populations. Similarly to municipality size, also the character of local party competition proved to be a very strong determinant of female success, as increasing nationalisation of local party systems had a considerable (expected) negative effect on the number of women in local councils (H10). The considerably different effects of both variables at the level of representation versus the level of candidacy suggest once again that there may not be a direct relationship between both levels analysed.

As well as in the case of candidacy, also on the level of representation, we have to refuse the assumption that higher quality of life will foster the opportunities of women to successfully get involved in making decisions about politics in their community (H2). Thus, higher quality of life in Czech municipalities is not associated with higher political participation of women. On the contrary, both indicators of gendered context (or openness of local environment to women, respectively) worked in the expected direction. Thus, not only the share of previous female councillors in a given city (H6), but also women's representation on corporate boards of firms owned by the same city (H8) strongly increased the size of women's representation in city councils.

Finally, looking at Model 2, which included the lagged version of the previous female councillors variable, the dependent variable was affected by all independent variables in the same way. Not only did the direction of their effects remain unchanged, but at the same time, the inclusion of the lagged variable also had a minor effect on the strength of most independent variables. So, most of them kept their strong effects on female representation in Czech city councils, including the previous female councillors variable, whose positive effect declined the most but was still much stronger than at the candidacy level. 
Overall, Czech women were much more successful in smaller cities with lower quality of life which had less nationalised local party systems but at the same time were characterised by more strongly gendered contexts in the sense of previous female representation, both in city councils and on corporate boards of firms owned by these cities.

Table 3. Evaluation of the hypotheses - determinants of women's emergence and success in elections to Czech city councils, 2018

\begin{tabular}{|c|c|c|c|}
\hline & \multirow{2}{*}{$\begin{array}{l}\text { Expected } \\
\text { influence }\end{array}$} & Model 1 & Model 2 \\
\hline & & \multicolumn{2}{|c|}{ Real influence } \\
\hline \multicolumn{4}{|c|}{ Female candidates } \\
\hline$H_{1}:$ Quality of Life Index & + & NO & NO \\
\hline$H_{3}:$ Municipality size $(\log )$ & + & YES & YES \\
\hline$H_{5}:$ Previous female councillors & + & YES & YES \\
\hline$H_{7}:$ Gender Index & + & NO & YES \\
\hline$H_{9}:$ LPSN & - & YES & NO \\
\hline \multicolumn{4}{|c|}{ Female winners } \\
\hline$H_{2}:$ Quality of Life Index & + & NO & NO \\
\hline H4: Municipality size (log) & - & YES & YES \\
\hline$H_{6}$ : Previous female councillors & + & YES & YES \\
\hline$H_{8}:$ Gender Index & + & NO & YES \\
\hline$H_{10}:$ LPSN & - & YES & YES \\
\hline
\end{tabular}

Source: Author.

Note: Expected influence: positive (+), negative (-); real influence: YES - results consistent with hypothesis, $\mathrm{NO}$ - results inconsistent with hypothesis.

\section{Conclusions}

The aim of this paper was to analyse the effect of quality of life, together with other factors, on both female candidates' willingness to run for office and women's descriptive representation in the 2018 local elections in Czech cities, or more specifically municipalities with extended powers. Our results are, in some respects, unexpected and ambiguous, especially in comparison with studies analysing the determinants of women's representation in traditional democracies of Western Europe. First, we found that the effect of some variables was different in the case of women's emergence and women's success in local elections. In the case of municipality size, the positive effect of size on women's emergence can be explained by fact that larger cities represent contexts which 
generate more access points for the emergence of women candidates (whether due to their larger electoral districts or due to the existence of more legislative parties making it more likely for one of them to nominate more women - with this strategy subsequently modelled by other parties as well). However, in contrast to the negative effect of size on women's success due to the desirability of office argument, the explanation is more difficult in the case of the Gender Index.

On the other hand, the positive effects of the size of women's previous representation in local politics apply especially on future women's representation. In the case of the number of women candidates, those effects are still positive but much weaker (similarly as there is only a weak effect of previous women's representation on subsequent election of female mayors). In light of these findings, we can suggest some existence of the incumbency effect (i.e. advantage of female incumbents over their female challengers). As a result, then, experience with women in the political process may not generally play an important role in facilitating a gradual growth of women's success along with their gradual mobility from lower to higher positions.

On the contrary, as the level of women's descriptive representation attained in a municipality in a specific election reproduces at a similar or growing level in the following election (given the overall linear growth of women's representation since 1990) in the same municipality, rather than shifting (spreading) to surrounding municipalities in the form of a contagion effect (see Maškarinec 2020), an important question for future research is whether women who win a council seat assume, in the following election term, a role similar to male party gatekeepers, effectively limiting further growth of the number of women both running and elected.

If confirmed, this hypothesis could eventually explain the different effect of the Gender Index on the share of female candidates (negative) versus the share of female winners (positive). Indeed, as business management positions come with not only prestige but also influence and considerable salaries, they can be expected to be gained primarily by councillors (women as well as men) with more years of experience and better positions in the party hierarchy. Overall, the question whether women's representation at different levels of governance is interrelated in any way, and whether different levels of representation have different influence on other levels, represents an under-researched field that warrants more attention in future.

Similarly, the issue of local party system nationalisation with its considerably variable effects, albeit mostly in the expect negative direction, warrants further research. Indeed, as evidenced by its ambiguous relationship with municipality size, local party system nationalisation may be one of the factors influencing women's representation, which tends to be higher in municipalities with more successful independents or local parties.

Finally, the failure to confirm the expected positive effect of quality of life on women's political representation, at the level of both candidacy and representation, 
invites the question of why women are more successful in municipalities with lower quality of life. Our working hypothesis is again linked with the desirability hypothesis. The drive to win representation and make decisions about the life of the community can be expected to be much stronger in municipalities with higher quality of life (where the electoral competition in terms of number of candidates per seat will also be stronger). This will affect precisely women, as men should be more likely to seek offices in cities which are more prestigious and whose councillors have more decision-making powers (i.e., larger cities), as well as in cities which are not affected by development problems. In contrast, communities with lower quality of life will see much fewer men take interest in local government, with a much larger political opportunity structure opening before women.

\section{References}

Alozie, N. and Manganaro, L. 1993. “Women's Council Representation: Measurement Implications for Public Policy." Political Research Quarterly 46 (2): 383-398. https://doi.org/10.1177/106591299304600210

Balík, S. 2008. Česká komunální politika v obcích s rozšířenou působností. Koalice, voličské vzorce a politické strany na místní úrovni v letech 1994-2006. Brno: CDK.

Balík, S., Gongala, P. and Gregor, K. 2015. Dvacet let komunálních voleb v ČR. Brno: CDK.

Bernard, J. 2012. “Individuální charakteristiky kandidátů ve volbách do zastupitelstev obcí a jejich vliv na volební $\quad$ výsledky.” $\quad$ Sociologický $\quad$ časopis $48 \quad$ 613-640. https://doi.org/10.13060/00380288.2012.48.4.05

Bláha, P. and Maškarinec, P. 2020. "Politická reprezentace žen v zastupitelstvech krajských měst: kvalitativní komparativní analýza (QCA) komunálních voleb v České republice v roce 2018." Acta Fakulty filozofické Západočeské univerzity v Plzni 12 (1): 1-18. https://doi.org/10.24132/actaff.2020.12.1.2

Bochsler, D. 2006. "The Nationalization of Political Parties. A triangle model, applied on the Central and Eastern European countries." CEU Political Science Journal 1 (4): 6-37.

Bochsler, D. 2010. "Measuring party nationalisation: A new Gini-based indicator that corrects for the number of units." Electoral Studies 29 (1): 155-168. https://doi.org/10.1016/j.electstud.2009.06.003

Bougouffa, I. and Permana, A.S. 2018. "A Study on the Linkages between Residential Satisfaction and the Overall Quality of Life in Bandar Tun Razak Area of Kuala Lumpur City, Malaysia." Applied Research in Quality of Life 13: 991-1013. https://doi.org/10.1007/s11482-017-9570-3

Bowling, A. and Windsor, J. 2001. "Towards the Good Life: A Population Survey of Dimensions of Quality of Life." Journal of Happiness Studies 2: 55-82. https://doi.org/10.1023/A:1011564713657

Bullock, C.S. III. and MacManus, S.A. 1991. "Municipal Electoral Structure and the Election of Councilwomen." Journal of Politics 53 (1): 75-89. https://doi.org/10.2307/2131721

Caramani, D. 2004. The Nationalization of Politics. The Formation of National Electorates and Party Systems in Western Europe. Cambridge: Cambridge University Press. https://doi.org/10.1017/CB09780511616662

Carroll, S.J. 1994. Women as Candidates in American Politics. Bloomington: Indiana University Press. 
Chhibber, P. and Kollman. K. 2004. The Formation of National Party Systems: Federalism and Party Competition in Canada. Great Britain. India. and the United States. Princeton. NJ: Princeton University Press.

Crowder-Meyer, M. and Smith, A.R. 2015. "How the strategic context affects women's emergence and success in local legislative elections." Politics, Groups, and Identities 3 (2): 295-317. https://doi.org/10.1080/21565503.2015.1035286

Crowder-Meyer, M., Kushner Gadarian, S. and Trounstine, J. 2015. "Electoral institutions, gender stereotypes, and women's local representation." Politics, Groups, and Identities 3 (2): 318-334. https://doi.org/10.1080/21565503.2015.1031803

Čopík, J., Kopřiva, R. and Čmejrek, J. 2019. “Mayors as a variable in typologies of local governments: a case study of the Czech Republic." Local Government Studies [Online first]. https://doi.org/10.1080/03003930.2019.1699069

CZSO. 2020. Czech Statistical Office's Public Database. Prague: Czech Statistical Office. [online]. [cit. 20. 10. 2020]. Available at: http://vdb.czso.cz/

de Miguel, C. 2017. "The role of electoral geography in the territorialization of party systems." Electoral Studies 47: 67-83. https://doi.org/10.1016/j.electstud.2016.11.013

Dodeigne, J., Close, C. and Teuber, F. 2020. "Nationalisation of local party systems in Belgium (1976-2018): the combined effects of municipality size and parliamentary parties' dominance." Local Government Studies [Online first]. https://doi.org/10.1080/03003930.2020.1802251

Ennser-Jedenastik, L. and Hansen, M.E. 2013. "The Contingent Nature of Local Party System Nationalisation: The Case of Austria 1985-2009." Local Government Studies 39 (6): 777-791. https://doi.org/10.1080/03003930.2012.675328

Faka, A. 2020. "Assessing Quality of Life Inequalities. A Geographical Approach." ISPRS International Journal of Geo-Information (10): 600. https://doi.org/10.3390/ijgi9100600

Gwiazda, A. 2016. Democracy in Poland. Representation, participation, competition and accountability since 1989. Oxon: Routledge. https://doi.org/10.4324/9781315680118

Hájek, L. and Balík, S. 2020. Komunální volby v roce 2018. Brno: Masarykova univerzita.

Haman, M. and Školník, M. 2020. "Socioeconomic or Political Variables? The Determinants of Voter Turnout in Czech Municipalities." Sociológia 52 (3): 222-244. https://doi.org/10.31577/sociologia.2020.52.3.10

Harbers, I. 2010. "Decentralization and the Development of Nationalized Party Systems in New Democracies: Evidence From Latin America." Comparative Political Studies 43 (5): 606-627. https://doi.org/10.1177/0010414008330285

Harbers, I. 2017. "Spatial Effects and Party Nationalization: The Geography of Partisan support in Mexico." Electoral Studies 47: 55-66. https://doi.org/10.1016/j.electstud.2016.11.016

Illner, M. 2003. "Thirteen years of reforming sub-national government in the Czech Republic." In: N. Kersting and A. Vetter (eds.). Reforming Local Government in Europe: Closing the Gap between Democracy and Efficiency. Opladen: Leske + Budrich, 261-281. https://doi.org/10.1007/978-3-663-11258-7_13

Inglehart, R. 1997. Modernization and Postmodernization: Cultural, Economic, and Political Change in 43 Societies. Princeton: Princeton University Press. 
Inglehart, R. and Norris, P. 2003. Rising tide: Gender equality and cultural change around the world. Cambridge: Cambridge University Press. https://doi.org/10.1017/CB09780511550362

Inglehart, R., Norris, P. and Welzel, C. 2002. “Gender equality and democracy.” Comparative Sociology 1 (34): 321-345. https://doi.org/10.1163/156913302100418628

Inglehart, R. and Welzel, C. 2005. Modernization, Cultural Change, and Democracy: The Human Development Sequence. Cambridge: Cambridge University Press.

Ira, V. and Andráško, I. 2007. “Kvalita života z pohl’adu humánnej geografie.” Geografický časopis 59 (2): 159-179.

Janský, P., Krotil, K. and Pavlas, T. 2015. Bereme ženy na palubu. Analýza zastoupení žen a mužů ve vedení veřejných firem. Praha: Otevřená společnost/Národohospodářský ústav AV ČR/Byznys pro společnost.

Jüptner, P. 2008. "Local Lists in the Czech Republic.” In: M. Reiser and E. Holtmann (eds.). Farewell to the Party Model? Independent Local Lists in East and West European Countries. Baden-Baden: VS Verlag für Sozialwissenschaften, 21-38. https://doi.org/10.1007/978-3-531-90923-3_3

Jones, M.P. and Mainwaring, S. 2003. "The Nationalization of Parties and Party Systems. An Empirical Measure and an Application to the Americas." Party Politics 9 (2): 139-166. https://doi.org/10.1177/13540688030092002

Lijphart. A. 2012. Patterns of Democracy: Government Forms and Performance in Thirty-Six Countries. New Haven/London: Yale University Press.

Karnig, A.K. and Walter, O.B. 1976. "Election of Women to City Councils.” Social Science Quarterly 56 (4): 605-613.

Kazemzadeh-Zow, A., Darvishi Boloorani, A., Samany, N.N., Toomanian, A. and Pourahmad, A. 2018. “Spatiotemporal modelling of urban quality of life (UQoL) using satellite images and GIS." International Journal of Remote Sensing 39 (19): 6095-6116. https://doi.org/10.1080/01431161.2018.1447160

Kjaer, U. and Elklit, J. 2010. “Local Party System Nationalisation: Does Municipal Size Matter?” Local Government Studies 36 (3): 425-444. https://doi.org/10.1080/03003931003730451

Kasuya, Y. and Moenius, J. 2008. "The nationalization of party systems: Conceptual issues and alternative district-focused $\quad$ measures." $\quad$ Electoral $\quad$ Studies $27 \quad$ (1): $126-135$. https://doi.org/10.1016/j.electstud.2007.09.004

Krook, M.L. 2010. “Women's Representation in Parliament: A Qualitative Comparative Analysis.” Political Studies 58 (5): 886-908. https://doi.org/10.1111/j.1467-9248.2010.00833.x

Kruntorádová, I. 2015. Politické aspekty financování českých měst. Praha: Karolinum.

Lyons, P. and Linek, L. 2010. “Party System Nationalisation and Non-uniform Vote Switching. Evidence from the Czech Republic.” Sociologický časopis $46 \quad$ (3): 375-399. https://doi.org/10.13060/00380288.2010.46.3.03

Lysek, J. 2016. "Tackling Bureaucracy Growth in Time of Crisis: The Case of Czech Statutory Cities." Lex Localis - Journal of Local Self-Government 14 (4): 783-806. https://doi.org/10.4335/14.4.783806(2016)

Martinussen, P.E. 2004. “Government Performance and Political Accountability at Subnational Level: The Electoral Fate of Local Incumbents in Norway." Scandinavian Political Studies 27 (3): 227-259. https://doi.org/10.1111/j.1467-9477.2004.00105.x 
Maškarinec, P. 2015. "Nationalisation of the Czech Local Party System: Case Study of the 2010 Local Elections in Municipalities with Extended Powers." Sociológia 47 (6): 625-656.

Maškarinec, P. 2016. “Determinants of Women's Descriptive Representation on the City Boards of the Czech Statutory Cities after the Local Elections of 2014." Slovak Journal of Political Science 16 (2): 113-133. https://doi.org/10.1515/sjps-2016-0006

Maškarinec, P. 2019a. “Does Gender Matter? Determinants of Women's Representation on Corporate Boards of Firms Owned by the Czech Statutory Cities." Lex Localis - Journal of Local Self-Government 14 (4): 961-984. https://doi.org/10.4335/17.4.961-984(2019)

Maškarinec, P. 2019b. Ženy a lokální politika. Komunální volby v České republice v letech 1994-2018 z pohledu politické reprezentace žen. Brno: CDK.

Maškarinec, P. 2020. "Spatial Dimensions of Female Political Participation: Regional Perspective of Women's Descriptive Representation in Czech Local Councils, 1994-2018." ISPRS International Journal of Geo-Information 9 (12): 729. https://doi.org/10.3390/ijgi9120729

Maškarinec, P. and Klimovský, D. 2016. "Independent Candidates in the Local Elections of 2014 in the Czech Republic and Slovakia: Analysis of Determinants of Their Successfulness." Lex Localis - Journal of Local Self-Government 14 (4): 853-871. https://doi.org/10.4335/14.4.853-871(2016)

Maškarinec, P., Klimovský, D. and Danišová, S. 2018. "Politická reprezentace žen na pozicích starostek v Česku a na Slovensku vletech 2006-2014: Srovnávací analýza faktorů úspěšnosti.” Sociologický časopis 54 (4): 529-560. https://doi.org/10.13060/00380288.2018.54.4.413

Maškarinec, P., Klimovský, D. and Bláha, P. 2019. Where Have All the Women Gone? Women's Political Representation in Local Councils of Czech and Slovak Towns, 1994-2014. Praha: Dokořán.

Mizgajski, A., Walaszek, M. and Kaczmarek, T. 2014. "Determinants of the Quality of Life in the Communes of the Poznań Agglomeration: A Quantitative Approach.” Quaestiones Geographicae 33 (4): 67-80. https://doi.org/10.2478/quageo-2014-0050

Murgaš, F. 2016. "Geographical conceptualization of quality of life." Ekológia 35 (4): 309-319. https://doi.org/10.1515/eko-2016-0025

Murgaš, F. 2019. “Kvalita života jako prediktor voleb prezidenta Česka v letech 2013 a 2018.” In: V. Klímová and V. Žítek (eds.). XXII. mezinárodní kolokvium o regionálních vědách. Brno: Masarykova univerzita, 772-780. https://doi.org/10.5817/CZ.MUNI.P210-9268-2019-97

Murgaš, F. and Klobučník, M. 2016. "Municipalities and Regions as Good Places to Live: Index of Quality of Life in the Czech Republic." Applied Research in Quality of Life 11: 553-570. https://doi.org/10.1007/s11482-014-9381-8

Murgaš, F. and Drápela, E. 2020. "Quality of Urban Life in Socially Excluded Communities of Liberec Region." International Journal of Community Well-Being 3: 323-339. https://doi.org/10.1007/s42413-01900040-y

Murgaš, F. and Petrovič, F. 2020. "Quality of life and quality of environment in Czechia in the period of the COVID-19 pandemic." Geografický časopis $72 \quad$ (3): 261-274. https://doi.org/10.31577/geogrcas.2020.72.3.13

Norris, P. 1987. Politics and Sexual Equality: The Comparative Position of Women in Western Democracies. Boulder: Lynne Rienner. 
Obce v datech. 2020. Obce v datech. [online]. [cit. 20. 10. 2020]. Available at: https://www.obcevdatech.cz/ Ondercin, H.L. and Welch, S. 2009. "Comparing predictors of women's congressional election success." American Politics Research 37 (4): 593-613. https://doi.org/10.1177/1532673X08325198

Otevřená společnost. 2020. Genderová mapa. [online]. [cit. 20. 10. 2020]. Available at: http://www.genderovamapa.cz/

Peach, N.D. and Petach, L.A. 2015. "Development and Quality of Life in Cities." Economic Development Quarterly 30 (1): 32-45. https://doi.org/10.1177/0891242415620277

Phillips, D. 2006. Quality of Life. Concept, Policy and Practice. Oxon: Routledge. https://doi.org/10.4324/9780203356630

Potluka, O., Svecova, L. and Zarubova, L. 2020. “Do nonprofit leaders challenge political leaders?” CEPS Working Paper Series (17). Basel: Center for Philanthropy Studies.

Regulska, J., Fried, S. and Tiefenbacher, J. 1991. "Women, Politics and Place: Spatial Patterns of Representation in New Jersey." Geoforum 22 (2): 203-221. https://doi.org/10.1016/00167185(91)90008-E

Rinner, C. 2007. "A geographic visualization approach to multi-criteria evaluation of urban quality of life." International Journal of Geographical Information Science 21 (8): 907-919. https://doi.org/10.1080/13658810701349060

Rišová, K. and Pouš, R. 2018. "Urban facilities in the quality of life research: a case study of Banská Bystrica city (Central Slovakia)." $\quad$ Geografický časopis $59 \quad$ (2): $159-179$. https://doi.org/10.31577/geogrcas.2018.70.2.06

Ryšavý, D. and Bernard, J. 2013. “Size and Local Democracy: the Case of Czech Municipal Representatives.” Local Government Studies 39 (6): 833-852. https://doi.org/10.1080/03003930.2012.675329

Ryšavý, D. and Šaradín, P. 2010. "Straníci, bezpartijní a nezávislí zastupitelé na českých radnicích." Sociologický časopis 46 (5): 719-743. https://doi.org/10.13060/00380288.2010.46.5.02

Siaroff, A. 2000. "Women's Representation in Legislatures and Cabinets in Industrial Democracies." International Political Science Review 21 (2): 197-215. https://doi.org/10.1177/0192512100212005

Sloboda, M. 2014. "Women's participation and Incumbency Advantage in Slovak Cities: the Case Study of Mayoral elections in Slovakia." Socialiniai tyrimai/Social Research 36 (3): 101-112.

Smith, A.R., Reingold, B. and Owens, M.L. 2012. “The Political Determinants of Women's Descriptive Representation in Cities." Political Research Quarterly 65 (2): 315-329. https://doi.org/10.1177/1065912910395327

Spáč, P., Voda, P., Balík, S. and Pink, M. 2018. “Politika vykrmování na regionální úrovni. Případ dotací pro obce ve Středočeském kraji." Sociologický časopis $54 \quad$ (4): 499-528. https://doi.org/10.13060/00380288.2018.54.4.412

Spicer, Z., McGregor, M. and Alcantara, C. 2017. "Political opportunity structures and the representation of women and visible minorities in municipal elections." Electoral Studies 48: 10-18. https://doi.org/10.1016/j.electstud.2017.01.002

Stauber, J. 2017. “Institutionalization of Nationalized Party System: The Czech Case.” Acta Politologica 9 (2): 46-65. https://doi.org/10.14712/1803-8220/12_2017 
Steyvers, K. and Heyerick, A. 2017. "Fifty Shades of Rokkan? Reconceiving Local Party System Nationalisation in Belgium." Croatian and Comparative Public Administration 17 (4): 509-538. https://doi.org/10.31297/hkju.17.4.1

Strmiska, M., Chytilek, R., Šedo, J. and Eibl, 0. 2009. Volební komplexy zemí V4. Studie k pojetí víceúrovňového volebního prostoru. Brno: $\mathrm{CDK}$.

Šaradín, P. 2004. “Neparlamentní subjekty ve volbách do obecních zastupitelstev." Politologický časopis 11 (1): 109-120.

Šaradín, P., Outlý, J., Soukop, M. and Vrabková, I. 2019. “Politika na půl úvazku aneb Neuvolnění starostové: Jak fungují jejich obce?" Sociologický časopis $55 \quad$ (4): 503-522. https://doi: 10.13060/00380288.2019.55.4.475

Trounstine, J. 2011. “Evidence of a Local Incumbency Advantage.” Legislative Studies Quarterly 36 (2): 255280. https://doi.org/10.1111/j.1939-9162.2011.00013.x

Víšek, T., Dohnalová, R. and Král’ová, U. 2012. Využití plného potenciálu žen v české ekonomice. Praha: McKinsey \& Company.

Voda, P. and Svačinová, P. 2020. “To Be Central or Peripheral? What Matters for Political Representation in Amalgamated Municipalities?" Urban Affairs Review 56 (4): 1206-1236. https://doi.org/10.1177/1078087418824671

Vogt, D. 2017. "Politically Active Civil Society in the Liberec Region: traditional Associations, Independents or Local and Regional Political groupings in Municipal Elections 2010 and 2014." Acta Politologica 9 (3): 22-45. https://doi.org/10.14712/1803-8220/15_2017

Welch, S. and Karnig, A.K. 1979. "Correlates of Female Office Holding in City Politics." The Journal of Politics 41 (2): 478-91. https://doi.org/10.2307/2129774

Weziak-Białowolska, D. 2016. "Quality of life in cities - Empirical evidence in comparative European perspective." Cities 58: 87-96. https://doi.org/10.1016/j.cities.2016.05.016 